\title{
French as a Second Language Teacher Candidates' Language Proficiency and Confidence: Exploring the Influences of a Home- stay Practicum Experience
}

\author{
Callie Mady \\ Schulich School of Education, Nipissing University, Canada
}

\begin{abstract}
Teacher language proficiency and confidence influences students' classroom experiences. With the view to supporting French as a second language teacher candidates' language development, 15 teacher candidates participated in a home-stay practicum experience within a French milieu. This study sought to explore teacher candidates' self-concept of proficiency and their confidence pre and post-experience. Both qualitative and quantitative findings show an increase in perceived proficiency and confidence.
\end{abstract}

Index Terms-French as a second language education, second language teacher proficiency, second language teacher confidence

\section{INTRODUCTION}

Canada, the country in which this study was conducted, has two official languages: English and French. As such, Canadians can access the services of the federal government in either language. Although federal policies protect the right of minority French speakers to have an education in French, education in a second language is under the purview of the provinces. Ontario is the provincial context for this study. In Ontario, it is obligatory for students to study French as a second language (FSL) in the English stream. Core French, the program in which French is delivered as a subject in short daily periods, is obligatory while more intensive options such as French immersion are optional. Most FSL teachers in the province have completed one of these programs during their schooling.

In order to become a teacher in the province of Ontario, students must obtain an undergraduate degree and a two-year Bachelor of Education degree. The study described below was conducted with FSL teacher candidates enrolled in the second year of their Bachelor of Education program. It sought to examine the influence of a home-stay practicum experience on FSL teacher candidates' concept of their language proficiency confidence.

\section{LITERATURE REVIEW}

In general, teachers' subject knowledge has an impact on student achievement (Pachler, Evans and Lawes, 2007; Tsiu, 2003). As it pertains to second language teachers, Banno (2003) highlights that sufficient language proficiency is a required component in becoming a good language teacher. Teacher language proficiency has also been linked to competency elsewhere (Ellis, 2005). It is not surprizing then that teachers who are native speakers are often seen as advantaged (Freeman, 2016). More specifically, teacher French language proficiency has been found to influence not only their students' FSL acquisition (Bayliss \& Vignola, 2007), but also teachers' own confidence (Murdoch, 1994). Cullen (2002) associated lower proficiency levels with lack of self confidence in the class. Research has shown a lower self-perceived proficiency to be associated with less target language use (Fraga-Cañadas, 2010; Yilmaz, 2011). In fact, in Ontario, Canada the context of this study, educational stakeholders have revealed concerns about teacher proficiency (Salvatori, 2009). This concern is particularly acute in the province of Ontario where the demand for FSL teachers cannot be met, opening the door for less than proficient teachers being hired. Given that lack of opportunity to use French in a French environment can lead to language loss (Harley, 1994), the new lengthened two-year Bachelor of Education program, in the context of this study, requires additional commitment from teacher candidates to maintain/improve their French skills in English-dominant programs and contexts.

Although advantageous, seeking opportunities to use French in a French milieu comes with challenges. Teachers, for example, have been found to be hesitant to speak French with native speakers for fear of judgment. Another identified challenge to spending time in a French milieu is finances; teachers in Salvatori's (2007) research, for example, recognized the value of such an experience but revealed the cost as prohibitive.

In recognition of the potential barriers and the need to maintain/improve the French proficiency FSL teachers, the Ontario Ministry of Education provided financial support to subsidize a group of 15 FSL teacher candidates to spend two weeks in a French-speaking environment. The FSL teacher candidates lived with Francophone families, completed 
half-day practica in schools for one week and in the community for another, attended workshops the other half days, participated in events every other evening, and spent one weekend in Quebec City.

\section{METHOdOLOGY}

This study used pre and post-experience questionnaires and interviews to gather data. The pre-interview protocol had two questions pertaining to participants' FSL learning, one about their French proficiency and the last about their confidence level. The last two questions were reposed post-experience. The questionnaire had 11 statements on which the teacher candidates rated themselves using a five-point Likert scale pre and post-experience.

All interviews were recorded and transcribed. The transcripts were analyzed identifying common themes. The questionnaire provided descriptive data pre and post-experience as well as being analyzed to explore statistical differences.

\section{Participants}

Fifteen teacher candidates took part in the home stay experience in Trois Pistoles, Quebec. All of the teacher candidates had an undergraduate degree and were enrolled in the second year of the two-year Bachelor of Education program. As it pertains to their elementary and secondary studies, eight teacher candidates revealed that they had learned FSL through the core ${ }^{1}$ French program, two through extended French and five through the French immersion program (see Table 1). As per their post-secondary studies, the majority $(n=12)$ completed a Bachelor of Arts with French as their major, two took French as a minor and one teacher candidate pursued French studies through individual courses.

TABLE 1

TEACHER CANDIDATES' FRENCH LEARNING EXPERIENCES

\begin{tabular}{ll} 
& TEACHER CANDIDATES’ \\
\hline Level of Study & Learning Context \\
Elementary/Secondary & Core French $(n=8)$ \\
& Extended French $(n=2)$ \\
& French immersion $(n=5)$ \\
\hline University & French as a major $(n=12)$ \\
& French as a minor $(n=2)$ \\
& Individual French courses $(n=1)$ \\
\hline
\end{tabular}

\section{FINDINGS}

Prior to participating in the home-stay practicum experience, FSL teacher candidates participated in an interview. The interviews revealed that none of the teacher candidates had extra-curricular opportunities to use their French in elementary or secondary school. The majority of teacher candidates $(n=11)$, however, did have experiences in a Frenchspeaking environment in their university career.

\section{A. Teacher Candidate Proficiency}

The teacher candidates were then asked to describe themselves as speakers of French. While all of the teacher candidates expressed a certain level of proficiency, they all also indicated the need to continue to improve:

Proficient in the sense that I still consider myself a student. So I, even though I will be teaching students, I still consider myself progressing towards the goal of being bilingual one day. I definitely do not think that I am at that point; I would like to be. And I will definitely continue to improve and work to improve my competencies. -Annick

I would say I am fluent. I can carry out conversations easily in French, but obviously there is still so many things I still don't know in French, like I said earlier I don't know a lot of scientific terms or different contexts, maybe situations that you wouldn't normally discuss. -Chloe

Three teacher candidates linked their proficiency to the program/level in which they would be comfortable teaching:

So, I feel I would be best situated, I am in the intermediate senior stream but I feel like I would be better as maybe core elementary teacher. -Ian

I would say that I feel confident enough to teach for sure at the core level. -Diane

When asked to describe experiences that influenced their proficiency level, all of the teacher candidates $(n=11)$ who had experiences living in a French context cited those opportunities as having a positive impact on their French proficiency:

When I went to Quebec all of a sudden everything clicked. I wasn't translating sentences in my head I was just kind of like understanding them. So I think that was a big development part for me. I really think that is a testament to how important oral French is and listening because growing up in the core it was all written and it just didn't really stick. Ian

\footnotetext{
${ }^{1}$ Core French is the study of the language in short daily periods; Extended French is the study of the language and additional subjects in French for approximately $25 \%$ of students' schedule; French immersion is the study of the language and other subjects through the language for a minimum of $50 \%$ of the school day.
} 
The teacher candidates were asked to identify experiences that prompted a change in their French proficiency. The majority of candidates identified intensive language exposure opportunities as experiences that prompted improvements in their language learning. Six teacher candidates made mention of their experiences in Francophone communities:

My third year I went to Chicoutimi so I think that really helped my oral proficiency. -Melanie

Being in an environment where you are forced to speak the language everyday where you are with people who are really passionate about learning French and you know we'd always correct each other and stuff in ways that I wouldn't be super embarrassed because we are all learning and now again I guess I am taking French now and just finding the same thing. -Brianna

\section{B. Confidence Levels}

When describing the programs in which the teacher candidates would be comfortable teaching, the majority of teacher candidates $(n=11)$ expressed having confidence to teach in the core French program.

I think core is kind of what I am aiming for. It's what I learned from so I know the system for sure. -Brianna

I feel core is better for me because I know what the classroom setting is like. -Lynne

Three candidates expressed confidence to teach in French immersion while one teacher candidate expressed confidence to teach in either program.

I really like the Immersion setting like I really like they were very tight knit and the kids were all really good they were really receptive to the French language which I like. I feel like in sore it might be a little harder, I know they don't like it as much when they're in core French. -Elaine

Teacher candidates were also asked to identify which Grades they felt confident teaching. All teacher candidates felt confident to teach the divisions in which they were going to receive their qualifications. Six teacher candidates related their preference for a higher grade to the greater opportunity for them to use more of their French.

I think that I am very confident in both. I think that I would personally be happier teaching Grade 7/8 or high school just because I feel that I have worked so hard to attain this level of proficiency that I would be very sad if I was just teaching la chaise, la porte. -Annick

I really really enjoy more senior divisions because I like French and I like to be able to speak French. -Diane

\section{Teacher Candidates Responses to Likert Scale Questions}

Teacher candidates were provided 11 statements and were asked to rate their level of confidence on a five-point scale of agreement that included a neutral option. When combining the strongly agree and agree categories, the majority of teacher candidates indicated confidence in all of the contexts provided through the statements (see Table 2). The three contexts that inspired the least confidence were: explaining a new concept to my students in French, speaking with other FSL teachers in French and writing a lesson plan in French. The three contexts that stimulated the most confidence were: listening to and understanding my students in French, listening to and understanding other FSL teacher candidates in French, and listening to and understanding other FSL teachers in French.

TABLE 2

TEACHER CANDIDATES LEVELS OF CONFIDENCE

\begin{tabular}{|c|c|c|c|c|c|c|c|}
\hline & $\begin{array}{l}\text { Strongly } \\
\text { agree }\end{array}$ & Agree & Disagree & $\frac{\text { Strongly }}{\text { Disagree }}$ & $\begin{array}{l}\text { Neither Agree or } \\
\text { Disagree }\end{array}$ & $\underline{\text { Total }}$ & $\frac{\text { Weighted }}{\text { Average }}$ \\
\hline \multirow[t]{2}{*}{ I am confident explaining a new concept to students in French. } & $6.67 \%$ & $80.00 \%$ & $0.00 \%$ & $0.00 \%$ & $13.33 \%$ & & \\
\hline & 1 & 12 & 0 & 0 & 2 & 15 & 2.67 \\
\hline I am confident speaking with other FSL teacher candidates in & $26.67 \%$ & $66.67 \%$ & $0.00 \%$ & $0.00 \%$ & $6.67 \%$ & & \\
\hline French. & 4 & 10 & 0 & 0 & 1 & 15 & 3.07 \\
\hline I am confident speaking with other FSL teachers in French. & $6.67 \%$ & $60.00 \%$ & $6.67 \%$ & $0.00 \%$ & $26.67 \%$ & & \\
\hline I am confident providing oral feedback to my students in & $6.67 \%$ & $80.00 \%$ & $6.67 \%$ & $0.00 \%$ & $6.67 \%$ & & \\
\hline French. & 1 & 12 & 1 & 0 & 1 & 15 & 2.80 \\
\hline \multirow[t]{2}{*}{ I am confident writing on the black/whiteboard in French. } & $13.33 \%$ & $60.00 \%$ & $20.00 \%$ & $0.00 \%$ & $6.67 \%$ & & \\
\hline & 2 & 9 & 3 & 0 & 1 & 15 & 2.73 \\
\hline I am confident writing a lesson plan in French. & $6.67 \%$ & $60.00 \%$ & $13.33 \%$ & $0.00 \%$ & $20.00 \%$ & & \\
\hline I am confident in listening to and understanding my students in & $33.33 \%$ & $60.00 \%$ & $0.00 \%$ & $0.00 \%$ & $6.67 \%$ & & \\
\hline French. & 5 & 9 & 0 & 0 & 1 & 15 & 3.13 \\
\hline I am confident in listening to and understanding other FSL & $26.67 \%$ & $73.33 \%$ & $0.00 \%$ & $0.00 \%$ & $0.00 \%$ & & \\
\hline teacher candidates in French. & 4 & 11 & 0 & 0 & 0 & 15 & 3.27 \\
\hline I am confident in listening to and understanding other FSL & $33.33 \%$ & $60.00 \%$ & $0.00 \%$ & $0.00 \%$ & $6.67 \%$ & & \\
\hline teachers in French. & 5 & 9 & 0 & 0 & 1 & 15 & 3.13 \\
\hline I am confident in reading teaching related resources or texts in & $20.00 \%$ & $73.33 \%$ & $0.00 \%$ & $0.00 \%$ & $6.67 \%$ & & \\
\hline French. & 3 & 11 & 0 & 0 & 1 & 15 & 3.00 \\
\hline
\end{tabular}




\section{Post-participation Qualitative Findings}

FSL teacher candidates were asked if and how this experience influenced their self-concept as a French speaker, and which experiences had an impact on that description. Secondly, they were asked if and how the experience influenced their confidence and what, if any, experiences played a role in their confidence level.

When asked how, if at all, the experience influenced their self-concept as a French speaker, all participants $(\mathrm{N}=15)$ recognized that the experience had positive effects. Some of the teacher candidates recognized an improvement in proficiency:

I think my abilities have... like I have much more ability to speak French now because I know that I can do it and I can live in French... like I can...I've never lived in French before, I've never spent twenty four hours speaking French so now I feel like I have lived a day in the life of a French speaker and I know that I can do it which is cool. So I feel like kind of a whole world of like going abroad and going to French places, like it's like: Okay I can do this and I'm capable. -Gail

I found that it was so much easier when people spoke naturally as opposed to slowing it down for me, so that really improved my self-concept as a speaker cause I could just understand the native language as opposed to someone who is a learner of French. I found myself being more myself as a native speaker. -Melanie

So before this experience, I believe I said...I always told people I was practiced at French. When they asked me, "Oh you know French!" I say, "Oh, I'm practiced" you know, and in my mind I was like I can always get by but now after this experience....see I'm afraid of the word bilingual, but I'd say fluent. Like I can go anywhere now and have a conversation and talk to people and I will say I'm fluent in French, not necessarily bilingual. -Lynne

Teacher candidates were asked to identify the experiences that influenced their self-concept. The vast majority of participants $(n=13)$ highlighted the importance of their host families:

Here, even with my famille d'accueil or with my host family they were so so nice about us speaking French and they were really impressed with us maybe that is because they are used to a lower level of French speaker but they were just like, "Oh you guys are fine to be French teachers, what are you even doing here?" So that was kind of a confidence booster. -Gail

Living with my host family, our mom she corrected our French often which was a good reminder so you know what you said wrong and you'd know what you were supposed to say instead so it was helpful. -Paige

Okay, well basically the experience here obviously like when I arrived Monique was like, "Wow you speak French like well already" and I'm like "Well thank you"...that little confidence boost but then it's like I wasn't making mistakes as I was going along, she was correcting me and I was learning, you know I was asking questions like everyday. It was just an opportunity to have an expert in front of you and milk it for what it's worth...yea. -Hailey

Some teacher candidates $(n=7)$ underscored the influence of the weekend trip to Quebec as being a factor in improving their self-concept as a French speaker:

I think a big defining moment for me was going to Quebec City... was just that moment of, "Wow, I'm talking to the locals in French" and I mean a couple of times, they would start speaking English and I would say, "Nope, I am here to practice my French, continue in French" and it would be fine, and we would just speak in French like it's no big deal. Lynne

Other FSL teacher candidates $(n=6)$ highlighted their practica as having a positive influence on their self-concept, interestingly they mentioned their community placements more frequently as opposed to their school placements:

Being at the daycare it kind of made me aware of the fact that I need to be very precise with how I talk because I find that if I speak French I will fumble a bit but the kids they need that like direct...they need a direct phrase or a direct sentence. So that has helped. -Olive

My interactions with my host teacher, Genevieve, during my placement, the physical education teacher, they had mentioned that I speak very well. I was surprised actually... pleasantly surprised actually that a lot of the vocabulary that I was a little bit worried about not knowing pertaining to dodgeball or some of the more specialized games, I actually understood and could interact with the students about...which was a pleasant surprise. I think I also learned in my myself that there is a lot more that I still need to learn. -Annick

Secondly, the FSL teacher candidates were asked how, if at all, the experience influenced their confidence. All teacher candidates $(\mathrm{N}=15)$ indicated that the experience had a positive impact on their confidence with higher confidence levels post-experience. Some teacher candidates highlighted the importance of continuing to seek out similar experiences in the future:

My confidence is so much higher going into...I have an interview in two weeks and I feel so much more confident about the French portion that I feel like I won't even be phased by it and I feel really, really ready to impress with my French which is really great because I feel like I'm in good practice and I want to keep that going. -Gail

I have already had other experiences abroad and this experience I would say did improve my French but maybe just brought it up to the same level it has been at other points so just remembering that as I advance, or as I continue in my career remembering to take time to go back to those experiences abroad to increase my level of French again. You definitely lose your French in the classroom sometimes so yea, interacting with students...they don't have the same level as Francophones so sometimes you need to bring yourself back to those experiences. -Diane 
When asked to identify the experiences that influenced their confidence, the vast majority $(n=13)$ of FSL teacher candidates mentioned the encouragement of others as having a positive impact on their confidence. The vast majority $(n=13)$ mentioned the important role of their host families:

I was having a conversation with my host family...the mom and I was just talking to her and then after she said, "Look at the level of the conversation, we are having right now" because we were talking about the school system in Ontario comparing it to Quebec, we were just talking about sort of troubled students and things like that and I went, "Wow, I never thought about it but we are having an intellectual conversation in French"...not just, "Oh, what did you eat for dinner today?" It was actually digging into deeper issues where I still needed help with a couple of words but I was kind of like, "Wow! You're right we are having a deep conversation in French not just surface level" and that was really cool. Those two things were big moments for me. -Lynne

So here, just being surrounded by the language all the time, my host family...you are constantly talking with your host family... you know during the day, at meal times, during activities like Shuffleboard, or other activities with the group. Also, the workshops that we have had here...so the phonetics workshop, that also really helps because we are learning how to pronounce certain sounds and that is going to carry over directly into how you are speaking, and you can practice that... and in return your confidence is going to go up when you're...when you know that you are pronouncing certain words and sounds correctly. -Chloe

Others underscored the importance of various other people and their positive impact on their confidence levels:

I think when people told us that we speak French well...like when we were in different places, in stores or mainly in Quebec City in the restaurants and stuff...they would be like, "Oh! You speak French really well. You're Anglophone, that's amazing!" That was a really cool thing to hear...like, "Oh! You're French is really good!" It's exciting a little bit to not feel like falling over my words all the time which is nice like it was nice to hear that...yea. -Elaine

So I feel like all of our confidence really really took a major boost just because I don't know we got so many compliments from people which is really maybe not the thing to put a lot of...not to put a lot of pressure on like getting compliments but it was still nice...like it was still really nice. -Gail

I would just say it is being surrounded by people who encourage you to take chances, all of the people here have been so generous and kind. They are always encouraging you to speak as much French as possible, even if you are making mistakes... they are correcting you, but they are doing it at the right time so that makes it less intimidating... while also just being surrounded by friends and our prof who encourages us to constantly speak as much French as possible and to continually better ourselves in the language that also helps. -Chloe

\section{E. Post-participation Quantitative Findings}

The same teacher candidates were asked to rate their level of confidence for the 11 statements following their experience in Quebec. When combining the strongly agree and agree categories, the vast majority of teacher candidates indicated confidence in all of the contexts provided through the statements (see Table 3). The three contexts that stimulated the least confidence as indicated by one participant $(n=1)$ were: I am confident explaining a new concept to students in French, I am confident writing on the black/whiteboard in French, I am confident in listening to and understanding my students in French, I am confident in listening to and understanding other FSL teacher candidates in French, and I am confident in listening to and understanding other FSL teacher in French. The three contexts that stimulated most confidence were: listening to and understanding other FSL teacher candidates in French, listening to and understanding other FSL teachers in French, and the item with the greatest difference pre and post experience: speaking with other FSL teacher candidates in French. 
TABLE 3

TEACHER CANDIDATES LEVELS OF CONFIDENCE POST-WORKSHOP

\begin{tabular}{|c|c|c|c|c|c|c|c|}
\hline & $\begin{array}{l}\text { Strongly } \\
\text { agree }\end{array}$ & $\underline{\text { Agree }}$ & $\underline{\text { Disagree }}$ & $\frac{\text { Strongly }}{\text { Disagree }}$ & $\begin{array}{l}\text { Neither Agree } \\
\underline{\text { or Disagree }}\end{array}$ & Total & $\frac{\text { Weighted }}{\underline{\text { Average }}}$ \\
\hline $\begin{array}{l}\text { I am confident explaining a new concept to } \\
\text { students in French. }\end{array}$ & $\begin{array}{c}33.33 \% \\
5\end{array}$ & $\begin{array}{c}60.00 \% \\
9\end{array}$ & $\begin{array}{r}6.67 \% \\
1\end{array}$ & $\begin{array}{r}0.00 \% \\
0\end{array}$ & $\begin{array}{c}0.00 \% \\
0\end{array}$ & 15 & 3.27 \\
\hline $\begin{array}{l}\text { I am confident speaking with other FSL teacher } \\
\text { French. }\end{array}$ & $\begin{array}{c}80.00 \% \\
12\end{array}$ & $\begin{array}{c}20.00 \% \\
3\end{array}$ & $\begin{array}{r}0.00 \% \\
0\end{array}$ & $\begin{array}{r}0.00 \% \\
0\end{array}$ & $\begin{array}{c}0.00 \\
0\end{array}$ & 15 & 3.80 \\
\hline $\begin{array}{l}\text { I am confident speaking with other FSL teachers in } \\
\text { French. }\end{array}$ & $\begin{array}{c}53.33 \% \\
8\end{array}$ & $\begin{array}{c}46.67 \% \\
7\end{array}$ & $\begin{array}{r}0.00 \% \\
0\end{array}$ & $\begin{array}{r}0.00 \% \\
0\end{array}$ & $\begin{array}{c}0.00 \% \\
0\end{array}$ & 15 & 3.53 \\
\hline $\begin{array}{l}\text { I am confident providing oral feedback to my } \\
\text { French. }\end{array}$ & $\begin{array}{c}53.33 \% \\
8\end{array}$ & $\begin{array}{c}46.67 \% \\
7\end{array}$ & $\begin{array}{r}0.00 \% \\
0\end{array}$ & $\begin{array}{r}0.00 \% \\
0\end{array}$ & $\begin{array}{c}0.00 \\
0\end{array}$ & 15 & 3.53 \\
\hline $\begin{array}{l}\text { I am confident writing on the black/whiteboard in } \\
\text { French. }\end{array}$ & $\begin{array}{c}26.67 \% \\
4\end{array}$ & $\begin{array}{c}66.67 \% \\
10\end{array}$ & $\begin{array}{r}6.67 \% \\
1\end{array}$ & $\begin{array}{r}0.00 \% \\
0\end{array}$ & $\begin{array}{c}0.00 \\
0\end{array}$ & 15 & 3.20 \\
\hline I am confident writing a lesson plan in French. & $\begin{array}{c}40.00 \% \\
6\end{array}$ & $\begin{array}{c}60.00 \% \\
9\end{array}$ & $0.00 \%$ & $\begin{array}{r}0.00 \% \\
0\end{array}$ & $\begin{array}{c}0.00 \% \\
0\end{array}$ & 15 & 3.40 \\
\hline $\begin{array}{l}\text { I am confident providing written feedback to my } \\
\text { French. }\end{array}$ & $\begin{array}{c}46.67 \% \\
7\end{array}$ & $\begin{array}{c}53.33 \% \\
8\end{array}$ & $\begin{array}{r}0.00 \% \\
0\end{array}$ & $\begin{array}{r}0.00 \% \\
0\end{array}$ & $\begin{array}{c}0.00 \\
0\end{array}$ & 15 & 3.47 \\
\hline $\begin{array}{l}\text { I am confident in listening to and understanding my } \\
\text { French. }\end{array}$ & $\begin{array}{c}66.67 \% \\
10\end{array}$ & $\begin{array}{c}26.67 \% \\
4\end{array}$ & $\begin{array}{r}6.67 \% \\
1\end{array}$ & $\begin{array}{r}0.00 \% \\
0\end{array}$ & $\begin{array}{c}0.00 \\
0\end{array}$ & 15 & 3.60 \\
\hline $\begin{array}{l}\text { I am confident in listening to and understanding } \\
\text { teacher candidates in French. }\end{array}$ & $\begin{array}{c}80.00 \% \\
12\end{array}$ & $\begin{array}{c}13.33 \% \\
2\end{array}$ & $\begin{array}{r}6.67 \% \\
1\end{array}$ & $\begin{array}{r}0.00 \% \\
0\end{array}$ & $\begin{array}{c}0.00 \\
0\end{array}$ & 15 & 3.73 \\
\hline $\begin{array}{l}\text { I am confident in listening to and understanding } \\
\text { teachers in French. }\end{array}$ & $\begin{array}{c}80.00 \% \\
12\end{array}$ & $\begin{array}{c}13.33 \% \\
2\end{array}$ & $\begin{array}{r}6.67 \% \\
1\end{array}$ & $\begin{array}{r}0.00 \% \\
0\end{array}$ & $\begin{array}{c}0.00 \\
0\end{array}$ & 15 & 3.73 \\
\hline $\begin{array}{l}\text { I am confident in reading teaching related resources } \\
\text { French. }\end{array}$ & $\begin{array}{c}66.67 \% \\
10\end{array}$ & $\begin{array}{c}33.33 \% \\
5\end{array}$ & $\begin{array}{r}0.00 \% \\
0\end{array}$ & $\begin{array}{r}0.00 \% \\
0\end{array}$ & $\begin{array}{c}0.00 \\
0\end{array}$ & 15 & 3.67 \\
\hline
\end{tabular}

To investigate change in the overall level of confidence expressed by the participants pre-post-experience using the mean scores on a 5-point scale, an independent-samples t-tests were performed (Table 4). All questions resulted in an increase in confidence post experience. Confidence level in speaking with other FSL teacher candidates increased from a mean of 3.07 to 3.80 . The independent-samples t-test was significant $t(28)=-2.714, p=0.011$. Confidence level of the participants speaking with other FSL teachers in French significantly increased from a mean of 2.20 to $3.53(t(28)=-$ $3.409, p=0.002$ ). Confidence in providing oral feedback to students in French significantly increased from a mean of 2.80 to $3.53(t(28)=-2.827, p=0.009)$. Confidence in writing lesson plans in French significantly increased from a mean of 2.33 to $3.40(t(28)=-2.978, \mathrm{p}=0.006)$. Confidence in providing written feedback to my students in French significantly increased from a mean of 2.80 to $3.47(t(28)=-2.57, p=0.016)$. Confidence in listening to and understanding other FSL teacher candidates in French significantly increased from a mean of 3.27 to $3.73(t(28)=-$ 2.411, $p=0.023$ ). Confidence in reading teaching related resources or texts in French significantly increased from a mean of 3.00 to $3.67(t(28)=-2.467, p=0.02)$. 
TABLE 4

AVERAGE RESPONSES TO SURVEY STATEMENTS BEFORE AND AFTER THE WORKSHOP

\begin{tabular}{|c|c|c|c|c|c|c|}
\hline \multirow{2}{*}{ Question } & \multirow{2}{*}{$\begin{array}{l}\text { Before } \\
\text { Mean }\end{array}$} & \multicolumn{2}{|c|}{ After } & \multirow{2}{*}{$S D$} & \multirow[t]{2}{*}{$t$} & \multirow[t]{2}{*}{$p$} \\
\hline & & $S D$ & Mean & & & \\
\hline $\begin{array}{l}\text { I am confident explaining a new } \\
\text { concept to students in French. }\end{array}$ & 2.67 & 1.113 & 3.27 & 0.594 & -1.843 & 0.076 \\
\hline $\begin{array}{l}\text { I am confident speaking with } \\
\text { other FSL teacher candidates in } \\
\text { French. }\end{array}$ & 3.07 & 0.961 & 3.80 & 0.414 & -2.714 & $0.011^{*}$ \\
\hline $\begin{array}{l}\text { I am confident speaking with } \\
\text { other FSL teachers in French. }\end{array}$ & 2.20 & 1.424 & 3.53 & 0.516 & -3.409 & $0.002 *$ \\
\hline $\begin{array}{l}\text { I am confident providing oral } \\
\text { feedback to my students in } \\
\text { French. }\end{array}$ & 2.80 & 0.862 & 3.53 & 0.516 & -2.827 & $0.009 *$ \\
\hline $\begin{array}{l}\text { I am confident writing on the } \\
\text { black/whiteboard in French. }\end{array}$ & 2.73 & 0.961 & 3.20 & 0.561 & -1.624 & 0.116 \\
\hline $\begin{array}{l}\text { I am confident writing a lesson } \\
\text { plan in French. }\end{array}$ & 2.33 & 1.291 & 3.40 & 0.507 & -2.978 & $0.006^{*}$ \\
\hline $\begin{array}{l}\text { I am confident providing written } \\
\text { feedback to my students in } \\
\text { French. }\end{array}$ & 2.80 & 0.862 & 3.47 & 0.516 & -2.570 & $0.016^{*}$ \\
\hline $\begin{array}{l}\text { I am confident in listening to and } \\
\text { understanding my students in } \\
\text { French. }\end{array}$ & 3.13 & 0.990 & 3.60 & 0.632 & -1.538 & 0.135 \\
\hline $\begin{array}{l}\text { I am confident in listening to and } \\
\text { understanding other FSL teacher } \\
\text { candidates in French. }\end{array}$ & 3.27 & 0.458 & 3.73 & 0.594 & -2.411 & $0.023^{*}$ \\
\hline $\begin{array}{l}\text { I am confident in listening to and } \\
\text { understanding other FSL teachers } \\
\text { in French. }\end{array}$ & 3.13 & 0.990 & 3.73 & 0.594 & -2.012 & 0.054 \\
\hline $\begin{array}{l}\text { I am confident in reading teaching } \\
\text { related resources or texts in } \\
\text { French. }\end{array}$ & 3.00 & 0.926 & 3.67 & 0.488 & -2.467 & $0.020^{*}$ \\
\hline
\end{tabular}

\section{DISCUSSION}

In the pre-experience interviews, FSL teacher candidates revealed that they did not have authentic experiences to use their French outside of their elementary and secondary school classrooms. Even where there were school trips to French-speaking regions, the trips were not focused on language use opportunities or development. None of the teacher candidates had routine extra-curricular opportunities to use their French nor any exposure to French in the communities where they grew up. This lack of exposure to authentic environments at a young age may contribute to the high rate of attrition in FSL studies at these levels (Lapkin, Mady, \& Arnott, 2009) and thus contribute to the insufficient number of FSL teacher candidates required to meet the demand (Ontario Public School Boards' Association, 2018). In fact, researchers have linked the shortfall of FSL teachers to the low official language bilingual rates (Arnott, Hart, Lapkin, Mady, Vandergrift \& Masson, 2015; Kitchenham \& Chasteauneuf, 2010). The majority of FSL teacher candidates, however, did have extracurricular opportunities in university and had language-learning experiences in a Frenchspeaking region. The teacher candidates who had immersive experiences described such experiences as being pivotal experiences for their language development.

The FSL teacher candidates were asked to describe their own level of proficiency, while all of the teacher candidates expressed a certain level of proficiency, they all also indicated the need to continue to improve. When asked to describe experiences that influenced their proficiency level, all of the teacher candidates $(n=11)$ who had experiences living in a French context cited those opportunities as having a positive impact on their French proficiency.

In terms of confidence pre-participation, the majority of teacher candidates $(n=11)$ expressed having confidence to teach in the core French program and all teacher candidates felt confident to teach the divisions in which they were going to receive their qualifications. This confidence was confirmed in the questionnaire responses that revealed FSL teacher candidate confidence on each of the 11 items. A link between proficiency and self-confidence is supported by past research (Bayliss \& Vignola, 2007; Murdoch, 1994).

Through the post-experience interviews, the FSL teacher candidates revealed an improvement in French proficiency that they related to the home-stay component of the program as well as the opportunities to use French in the community. Similarly, the teacher candidates cited an increase in confidence in the interviews and through the questionnaire. Again, they linked this increase in confidence to their experiences with their host families and other Francophone members of the community. This heightened confidence prompted them to expand their consideration of the levels and programs in which they plan to teach. Although remaining confident to teach in the divisions of their future qualifications, the teacher candidates widened their plans to consider teaching in other divisions. Likewise, more FSL teacher candidates, post-experience, indicated confidence to teach in immersion than those pre-experience. It is 
interesting to note then, in addition to confidence, some FSL teacher candidates revealed that their choice of program was related to their own past experiences in elementary school.

Given the FSL teacher candidates' lack of exposure to French outside of the classroom at the elementary and secondary levels, I suggest highlighting such opportunities and their positive impact to teachers with a view to increasing the number of intensive language learning experiences provided to students at the elementary and secondary levels. Experiences Canada and opportunities through Canadian Parents for French are two examples of organizations that facilitate such experiences. Further, school trips to French-speaking regions could be better harnessed so as to add a language development component. In addition, opportunities to use French outside of the classroom without the need for travel may prove beneficial.

FSL teacher candidates' proficiency and confidence improved due to this and previous authentic intensive French experiences. The teacher candidates also related their improvement to such opportunities and planned to seek them out in the future to maintain/improve their skills. In addition to suggesting such experiences for FSL students, I recommend continued provision of such opportunities for future FSL teachers. In particular, given the recognition of the important role of the home-stay component, I advocate for the intensive experiences that well-established home-stay programs can offer.

\section{REFERENCES}

[1] Arnott, S., Hart, D., Lapkin, S., Mady, C., Vandergrift, L. \& Masson, E. (2015). French as a Second Language in Canada: Potential for Collaboration. Council of Ministers of Education, Canada.

[2] Banno, E. (2003). A cross-cultural survey of students' expectations of foreign language teachers. Foreign Language Annals, $36(3), 339-346$.

[3] Cullen, R. (2002). The use of lesson transcripts for developing teachers' classroom language. In H. Trappes-Lomax \& G. Ferguson (Eds), Language in Language Teacher Education (219-38). Amsterdam: John Benjamins Publishing Company.

[4] Ellis, R. (2005). Principles of instructed second language learning. System 33(2): 209-24.

[5] Fraga-Cañadas, C. (2010). Beyond the classroom: Maintaining and improving teachers' language proficiency. Foreign Language Annals, 43(3), 395- 421.

[6] Freeman, D. (2016). Educating Second Language Teachers. Oxford: Oxford University Press.

[7] Kitchenham, A., \& Chasteauneuf, C. (2010). Teacher Supply and Demand: Issues in Northern Canada. Canadian Journal of Education, 33(4), 869-896.

[8] Lapkin, S., Mady, C., Arnott, S. (2009). Research perspectives on core French: A literature review. Canadian Journal of Applied Linguistics, 12 (2), 6-20.

[9] Murdoch, G. (1994). Language development provision in teacher training curricula. The ELT Journal, 48(3), $253-65$.

[10] Ontario Public School Boards' Association (2018). Meeting labour market needs for French as a second language instruction in Ontario. Toronto, Ontario: author.

[11] Pachler, N., Evans, M., \& Lawes, S. (2007). Modern foreign languages: Teaching school subjects 11-9. Oxford: Routledge.

[12] Salvatori, M. (2009). A Canadian perspective on language teacher education: Challenges and opportunities. Modern Language Journal, 92(2), 287-292.

[13] Tsui, S. (2003). Understanding expertise in teaching. Cambridge: Cambridge University Press.

[14] Yilmaz, C. (2011). Teachers' perception of self- efficacy, English proficiency, and instructional strategies. Social Behavior and Personality, 39(1), 91-100.

Callie Mady received her Bachelor of Arts at McGill University in 1987, her Bachelor of Education from Brock University in 1988, her Master of Arts in 2003 and her Doctor of Philosophy in 2006 from the Ontario Institute for Studies in Education of the University of Toronto. Her graduate degrees focused on second language education.

Callie is currently the Associate Dean in the Schulich School of Education at Nipissing University, North Bay, Ontario, Canada. Previously, she taught second languages at the elementary and secondary levels. Among her various publications, she co-edited a book with Arnett entitled Minority Populations in Canadian Second Language Education (Bristol, United Kingdom: Multilingual Matters, 2013). Her research interests include French as a second language education and multilingual language acquisition. In particular, her research focuses on minority populations in those areas-immigrants and students with learning difficulties. 